\title{
Tax Competition, Elastic Labor Supply, and Growth
}

\author{
ULRICH HANGE
}

CESIFO WORKING PAPER NO. 2338

CATEGORY 1: PuBlic FinANCE

JUNE 2008

\footnotetext{
An electronic version of the paper may be downloaded

- from the SSRN website: www.SSRN.com

- from the RePEc website: - from the CESifo website: 


\title{
Tax Competition, Elastic Labor Supply, and Growth
}

\begin{abstract}
In this paper we investigate the effects of tax competition in a simple endogenous growth model with elastic labor supply. Our analysis focuses on two issues. First, we show that all taxes, i.e. on capital, labor, and consumption, are harmful for growth. Second, we derive the optimal tax policy. A regional government chooses an inefficiently low tax rate on mobile capital in the presence of tax competition. In contrast, the tax rates on labor income and consumption are always set in order not to distort the consumption-leisure choice.
\end{abstract}

JEL Code: H21, H7, O23.

Keywords: tax competition, endogenous growth, elastic labor.

\author{
Ulrich Hange \\ Bezirk Oberbayern \\ Stabstelle \\ Prinzregentenstrasse 14 \\ 80538 Munich \\ Germany \\ ulrich.hange@bezirk-oberbayern.de
}

May 2008 


\section{Introduction}

Economic integration, enhancing the mobility of goods and factors between firms, households and regions, is expected to improve the allocation of resources. This may increase the welfare of citizens, and allow governments to better tailor publicgood levels according to the preferences of their mobile residents, as emphasized by Tiebout's (1956) seminal work. However, economic integration also implies a higher mobility of tax bases. Competing for mobile factors, governments may be forced to cut tax rates, causing a downward pressure on public goods and services.

While the literature on benefits and problems with regard to mobile tax bases is large, as surveyed e.g. by Wilson (1999) and Wellisch (2000), so far there exist only a few contributions investigating the nexus between tax competition and growth. This is astonishing, since most of the studies on tax competition deal with competition for mobile capital, and capital accumulation is one of the major driving forces of growth.

One exception is the work by Brueckner (1999, 2005) showing in an overlapping generations model how tax competition affects the incentive to save and, thus, the growth path of regions. It does so by sorting young and old households in different jurisdictions providing different levels of a (local) public good in response to agedependent demands. While Brueckner focuses on the benefit of fiscal decentralization emphasized by Tiebout (1956), Rauscher (2005) concentrates on a possible tax cut due to tax competition that may allow to restrain the Leviathan. As mentioned by Rauscher (2005) himself his model neglects some important features, e.g. savings by workers as in Lejour and Verbon (1997). Moreover, he assumes infinitely small regions whose tax policies do not influence the economic development in the rest of the world.

In this paper we try to remedy for some of these omissions and adopt a simple endogenous growth model developed by Turnovsky $(1999,2000)$. We assume, in the tradition of Frankel (1962) and Romer (1986), a positive externality associated with the economy-wide capital. It is well-known that under these circumstances, the competitive economy will not yield the socially optimal rate of growth, providing an inbuilt rationale for government intervention to subsidize capital. Moreover, this 
model provides a tractable framework for analyzing the regional tax policy depending on the number of regions competing for mobile capital and, thus, depending on the market power of regions. As we will show, the larger the number of regions, i.e. the harder the competition, the lower the tax rate on capital.

One further limitation of the existing literature on tax competition is that many contributions assume an immobile and inelastically supplied factor. If the regional government is allowed to tax this factor it has in fact a non-distortionary lump-sum tax at its disposal. In this paper we introduce elastic labor supply which lends an important role to wage income and consumption taxes in determining the optimal tax policy in the presence of tax competition. Except in the case of a small open economy, in which in fact there is no taxation, all taxes, i.e. on capital, labor, and consumption, influence growth. But while the capital income tax depends on the number of regions and thus on the degree of tax competition, the tax rates on labor income and consumption are always set so as not to distort the consumption-leisure choice.

Our analysis of the tax policy focuses on two general issues. Firstly, we conduct some comparative static exercises showing that all taxes reduce the return on capital and, thus, the growth factor. Moreover, an increase in any tax rate reduces labor supply and capital employment in the tax-increasing region while capital and labor employed in the other regions are increased. Secondly, we characterize the optimal tax system. In a first-best optimum, capital income should be subsidized in order to adjust the private return to the social return. A government in a closed economy maximizing the welfare of its citizens would choose this optimal tax policy. But a regional government competing for mobile capital chooses an inefficiently low level of subsidization.

The paper is organized as follows. Section 2 describes the model and gives the comparative static results. In Section 3 we derive the first-best allocation and characterize the efficiency-supporting tax system. Section 4 gives the optimal tax policy from the viewpoint of a single regional government, while Section 5 concludes, noting some possible extensions and caveats. Technical details are minimized throughout the main text and relegated to the Appendix. 


\section{The Model}

Consider a federation consisting of $I$ identical regions. In each region there is a mass one of identical firms, indexed by $m$. In period $t$ a representative firm in region $i$ produces a homogenous output according to

$$
Y_{t}^{i}(m)=F\left(A L_{t}^{i}(m), K_{t}^{i}(m)\right)
$$

where $K_{t}^{i}(m)$ denotes the firm's stock of capital and $A L_{t}^{i}(m)$ are the efficiency units of labor employed by the firm in region $i$. The production function is linear homogenous and strictly concave in $L_{t}^{i}$ and $K_{t}^{i}$ with positive, but diminishing marginal products, $F_{L}^{i}, F_{K}^{i}>0$ and $F_{L L}^{i}, F_{K K}^{i}<0 .{ }^{1}$ Note that strict concavity also implies

$$
F_{L L}^{i} F_{K K}^{i}-\left(F_{K L}^{i}\right)^{2}>0
$$

where $F_{K L}^{i}>0$ as a consequence of the assumption of linear homogeneity. Since all firms in a region are identical they will choose in equilibrium the same levels of capital and labor employment, i.e. $K_{t}^{i}(m)=K_{t}^{i}$ and $L_{t}^{i}(m)=L_{t}^{i}$ for all $m$, where $K_{t}^{i}$ and $L_{t}^{i}$ give the total employment of capital and labor in region $i$.

We further assume, in the tradition of Frankel (1962) and Romer (1986), a production externality associated with the economy-wide stock of capital. In particular, $A=K_{t}$, so that the efficiency of labor depends on the (average) stock of capital employed in the whole federation $K_{t}$. Production in region $i$ can now be described by

$$
Y_{t}^{i}=F\left(K_{t} L_{t}^{i}, K_{t}^{i}\right)
$$

Capital fully depreciates at the end of each period, so that its cost is $1+r_{t}^{i}$. Assuming perfect competition in each region's factor markets, the wage rate $w_{t}^{i}$ and the return on capital are determined by their respective private marginal products,

$$
w_{t}^{i}=K_{t} F_{L}^{i} \quad \text { and } \quad 1+r_{t}^{i}=F_{K}^{i} .
$$

There is a mass one of infinitely living, identical households or families in the whole federation. Each region $i$ is populated by $N^{i}$ immobile households. Each household

\footnotetext{
${ }^{1}$ In the following, subindices denote partial derivatives as long as they are not obviously time indices.
} 
is endowed with one unit of time which it allocates between leisure, $l_{t}^{i}$, and labor, $1-l_{t}^{i}$. Thus, total labor supply in region $i$ in period $t$ sums up to $L_{t}^{i}=N^{i}\left(1-l_{t}^{i}\right)$. Each family possesses the same stock of capital $K_{t} \cdot{ }^{2}$ Households invest their capital where it yields the highest return. As a consequence, in equilibrium the same net return on capital $R_{t}$ has to prevail in all regions,

$$
R_{t}=\left(1-\tau_{K}^{i}\right)\left(1+r_{t}^{i}\right) \quad \text { for all } \quad i=1, \ldots, I
$$

where $\tau_{K}^{i}$ denotes the (source-based) capital income tax rate in region $i$. Beside its capital income a household in region $i$ receives labor income (net of taxes) to finance her consumption $c_{t}^{i}$ and investment in capital $K_{t+1}$. Thus, the budget constraint of a family residing in region $i$ in period $t$ reads as

$$
K_{t+1}=R_{t} K_{t}+\left(1-\tau_{L}^{i}\right) w_{t}^{i}\left(1-l_{t}^{i}\right)-\left(1+\tau_{C}^{i}\right) c_{t}^{i}
$$

where $\tau_{L}^{i}$ and $\tau_{C}^{i}$ denote the tax rates on labor income and consumption, respectively. The objective of a family in region $i$ is to choose her leisure/labor time and consumption/investment to maximize lifetime utility described by a lognormal utility function $^{3}$

$$
U_{t}^{i}=\sum_{s=t}^{\infty} \rho^{s-t}\left[\ln c_{s}^{i}+\eta \ln l_{s}^{i}\right], \quad \text { with } \quad \eta>0, \quad 1>\rho>0,
$$

where $\rho$ gives the discount factor associated with the time preference. The first-order conditions are

$$
c_{t}^{i}=\left(\frac{1-\tau_{L}^{i}}{1+\tau_{C}^{i}}\right) \frac{w_{t}^{i} l_{t}^{i}}{\eta},
$$

\footnotetext{
${ }^{2}$ To avoid notational clutter we drop the region-specific index here. As is well-known from the standard Romer model, in equilibrium all households use their entire labor income and the same fraction of their capital income for consumption independently from where they reside. As a consequence, the assumption that all households start with the same stock of capital implies that they will also invest the same amount in capital.

${ }^{3}$ The use of the lognormal utility function is not only convenient but also actually less restrictive than it may appear. All of the following results continue to hold if we use an isoelastic utility function of the form $U_{t}^{i}=\sum_{s=t}^{\infty} \rho^{s-t} \gamma^{-1}\left[c_{t}^{i}\left(l_{t}^{i}\right)^{\eta}\right]^{\gamma}$, where $-\infty<\gamma \leq 0$. This would considerably complicate the analysis without changing the qualitative results.
} 


$$
\begin{aligned}
\frac{c_{t+1}^{i}}{c_{t}^{i}} & =\rho R_{t+1} \\
\frac{l_{t+1}^{i}}{l_{t}^{i}} & =\rho R_{t+1} \frac{w_{t}^{i}}{w_{t+1}^{i}},
\end{aligned}
$$

together with the transversality condition

$$
\lim _{t \rightarrow \infty} \lambda_{t}^{i} K_{t}=0
$$

where $\lambda_{t}^{i}$ is the shadow value of capital of a household living in region $i$. Condition (6a) demands that the marginal rate of substitution between leisure and consumption is equal to the relative price of these two goods after taxes. Condition (6b) reveals that not only all households in region $i$ but all families in the whole federation choose the same consumption growth factor. Hence, the aggregate growth factor within the federation is equal to the individual growth factor. Finally, condition (6c) describes the optimal time path for leisure depending on the ratio of the growth factors of consumption and the wage rate.

The government in region $i$ balances the public budget in each period $t$ according to the constraint

$$
\tau_{K}^{i}\left(1+r_{t}^{i}\right) K_{t}^{i}+\tau_{L}^{i} N^{i} w_{t}^{i}\left(1-l_{t}^{i}\right)+\tau_{C}^{i} N^{i} c_{t}^{i}=0
$$

Note that if one tax rate is positive at least one of the other tax rates must be negative, turning that tax into a subsidy.

\section{Macroeconomic Equilibrium}

In the appendix we show that the federation with identical regions is always on its balanced growth path implying the following two key relationships:

$$
\begin{aligned}
\frac{c_{t+1}^{i}}{c_{t}^{i}} & =\frac{w_{t+1}^{i}}{w_{t}^{i}}=\frac{K_{t+1}^{i}}{K_{t}^{i}}=\frac{K_{t+1}}{K_{t}}=\rho R, \\
l^{i} & =l_{t}^{i}=l_{t+1}^{i}>\frac{\eta}{1+\eta}, \quad \text { for all } i=1, \ldots, I .
\end{aligned}
$$

Equation (8) affirms that in equilibrium the growth factors of consumption, capital and wage rates are equal and the same in all regions of the federation. This growth factor remains constant over time and is equal to the net return to capital multiplied 
by the time preference factor $\rho$. Note that the return to capital depends on leisure time, i.e. the lower the leisure the higher the productivity of capital and thus the growth factor. Condition (9) states that leisure is constant over time as well, and gives a lower boundary for leisure to ensure that the transversality condition (6d) is met, i.e. that in addition to the whole labor income a constant fraction of the capital income is consumed.

Beside these relationships the macroeconomic equilibrium in the federation is determined by the following conditions:

Equilibrium capital allocation

$$
\left(1-\tau_{K}^{i}\right) F_{K}^{i}=R \quad \text { for all } i=1, \ldots, I
$$

Equilibrium growth factor

$$
\frac{c_{t+1}^{i}}{c_{t}^{i}}=\rho R \quad \text { for all } \quad i=1, \ldots, I
$$

Individual consumption-leisure ratio

$$
c_{t}^{i}=\left(\frac{1-\tau_{L}^{i}}{1+\tau_{C}^{i}}\right) \frac{K_{t} F_{L}^{i} l^{i}}{\eta} \quad \text { for all } \quad i=1, \ldots, I
$$

Individual budget constraint

$$
\left(1+\tau_{C}^{i}\right) c_{t}^{i}=(1-\rho) R K_{t}+\left(1-\tau_{L}^{i}\right) K_{t} F_{L}^{i}\left(1-l^{i}\right)
$$

Regional government's budget constraint

$$
\tau_{K}^{i} F_{K}^{i} K_{t}^{i}+\tau_{L}^{i} K_{t} F_{L}^{i} N^{i}\left(1-l^{i}\right)+\tau_{C}^{i} N^{i} c_{t}^{i}=0
$$

Regional labor market equilibrium

$$
L^{i}=N^{i}\left(1-l^{i}\right), \quad \text { for all } i=1, \ldots, I
$$

Federal capital constraint

$$
K_{t}=\sum_{i=1}^{I} K_{t}^{i}
$$


Federal goods market equilibrium

$$
K_{t+1}=\sum_{i=1}^{I}\left[F^{i}\left(K_{t} L^{i}, K_{t}^{i}\right)-N^{i} c_{t}^{i}\right] .
$$

For the following it is useful to derive the regional resource constraint. Insert the regional government's budget constraint (10e) into the individual budget constraint (10d) and using the properties of a linear homogenous production function yields

$$
c_{t}^{i}=\frac{R}{N^{i}}\left(N^{i} K_{t}-K_{t}^{i}\right)+\frac{F^{i}\left(K_{t} L^{i}, K_{t}^{i}\right)}{N^{i}}-(1-\rho) K_{t} .
$$

$N^{i} K_{t}-K_{t}^{i}$ denotes the net capital export of region $i$. In the case of identical regions this term is equal to zero in equilibrium.

Finally, using (8) in (5) the utility function of a family residing in region $i$ can also be written as

$$
U_{t}^{i}=\frac{1}{(1-\rho)} \ln c_{t}^{i}+\frac{\rho}{(1-\rho)^{2}} \ln \rho R+\frac{\eta}{(1-\rho)} \ln l^{i}
$$

Before we go on to derive the first-best policy and the behavior of regional governments, it is instructive to learn how changes in the tax rates in region $i$ influence the interest rate, the interregional capital allocation, and the leisure time. The effects around the optimum in the case of identical regions are examined formally in the appendix. Here we state the qualitative results:

$$
\begin{aligned}
\frac{\partial R}{\partial \tau_{X}^{i}}<0, \quad X=K, L, C, \\
\frac{\partial K_{t}^{i}}{\partial \tau_{X}^{i}}=-\frac{\partial K_{t}^{j}}{\partial \tau_{X}^{i}}(I-1)<0, \quad j \neq i, \\
\frac{\partial l^{i}}{\partial \tau_{X}^{i}}>0, \quad \frac{\partial l^{j}}{\partial \tau_{X}^{i}}<0, \quad j \neq i .
\end{aligned}
$$

As (13a) shows, an increase of any tax in region $i$ decreases the return on capital and thus the growth factor within the federation. The reason for this is revealed by (13b). The tax increasing region $i$ loses capital, while the capital employment in all other regions rises. Thus, the marginal productivity of capital falls in all other 
regions, which explains the decline in the interest rate throughout the federation. The increase in labor supply in the capital-winning regions indicated by (13c) does not compensate for this. The economic intuition is straightforward. Consider for example an increase in the tax on labor income, $\tau_{L}^{i}$. The higher tax rate implies a fall in the net wage rate in region $i$. Hence, households reduce their labor supply. This causes a reduction of labor employed by firms in region $i$ and a fall in the marginal product of capital. Therefore, capital leaves region $i$ until the net rates of return to capital within the federation are equalized again. This generates the fall in the economy-wide interest rate and growth.

\section{First-best Taxation}

We now consider the efficiency-supporting tax system. For this we act as a social planner maximizing the utility of a representative household in region $i$ subject to the condition that the utility of households in the other regions must reach at least an arbitrarily given, positive level $\bar{U}$, and subject to the resource constraints (10f), $(10 \mathrm{~g})$ and $(10 \mathrm{~h})$. Formally the optimization problem reads as

$$
\max \quad U_{t}^{i}=\sum_{s=t}^{\infty} \rho^{s-t}\left[\ln c_{s}^{i}+\eta \ln l^{i}\right], \quad \text { with } \quad \eta>0, \quad 1>\rho>0
$$

in the vectors $\left(c_{s}^{i}\right),\left(l^{i}\right),\left(K_{s}^{i}\right)$, and $\left(K_{s+1}\right), s \geq t$, subject to

$$
\begin{aligned}
U_{t}^{j} & \geq \bar{U} \quad j \neq i \\
K_{t+1} & =\sum_{i=1}^{I}\left[F^{i}\left(K_{t} L^{i}, K_{t}^{i}\right)-N^{i} c_{t}^{i}\right] \\
K_{t} & =\sum_{i=1}^{I} K_{t}^{i} \\
L^{i} & =N^{i}\left(1-l^{i}\right) .
\end{aligned}
$$

The solution to the central planner's problem gives us the first-order conditions (for all regions $i=1, \ldots, I$ )

$$
F_{K}^{i}=F_{K}^{j},
$$




$$
\begin{aligned}
\frac{c_{t+1}^{i}}{c_{t}^{i}} & =\rho\left[F_{L}^{i}\left(1-l^{i}\right)+F_{K}^{i}\right], \\
c_{t}^{i} & =\frac{K_{t} F_{L}^{i} l^{i}}{\eta} .
\end{aligned}
$$

Comparing these equations with the corresponding first-order conditions in a decentralized equilibrium (10a), (10b) and (10c) and using the regional government's budget constraint (10e) reveals that the efficiency-supporting tax system obeys the following rules: ${ }^{4}$

$$
\begin{aligned}
\tau_{K}^{i} & =\tau_{K}^{j}, \quad i, j=1, \ldots, I \\
\tau_{K}^{i} & =-\frac{K_{t} F_{L}^{i} N^{i}\left(1-l^{i}\right)}{F_{K}^{i} K_{t}^{i}} \\
\tau_{L}^{i} & =-\tau_{C}^{i} \quad \text { and } \quad \tau_{L}^{i}=-\frac{\eta\left(1-l^{i}\right) / l^{i}}{1-\eta\left(1-l^{i}\right) / l^{i}}
\end{aligned}
$$

The first equation (17a) states that the tax rates on capital should be the same in all regions in order to ensure an efficient interregional capital allocation. According to (17b) capital income should be subsidized so that the private return on capital equals the social return. Finally, (17c) reveals that any wage tax should be offset by an equivalent consumption tax rate so as not to distort the consumption-leisure choice. This result corresponds to the well-known Ramsey rule on optimal taxation postulating that all utility enhancing goods, i.e. consumption and leisure, should be taxed uniformly (if the utility function is multiplicatively separable in these goods). Note that labor income is subsidized as well. The reason for this is as follows: Since, in equilibrium, consumption exceeds labor income and the optimal tax policy requires $\tau_{L}^{i}=-\tau_{C}^{i}$, positive tax revenues can only be raised if $\tau_{L}^{i}<0 .{ }^{5}$ The economic intuition is that there are in fact two externalities at work. Firstly, the well-known

\footnotetext{
${ }^{4}$ Note that this tax system maximizes both utility and growth in each region.

${ }^{5}$ As pointed out by García-Peñalosa and Turnovsky (2006), the tax rate on capital must exceed that on labor income, $\tau_{K}^{i}>\tau_{L}^{i}$, since the consumption tax must finance the subsidy to both capital and labor, implying $\tau_{C}^{i}>-\tau_{K}^{i}$. Thus, in contrast to the conventional view, the above analysis provides a rationale for taxing mobile capital at least as much as immobile labor. Other studies reaching similar conclusions include Fuest and Huber (2001), and Koskela and Schöb (2002).
} 
positive impact of a greater federal stock of capital on the efficiency of labor. Secondly, a higher labor supply induced by a higher subsidy on labor raises the marginal productivity of capital, too, and induces a higher social return on capital. We summarize these results in

Proposition 1: A decentralized economy will replicate the first-best optimum if and only if

(i) the tax rates on capital are the same in all regions and

(ii) the tax rates are set according to

$$
\tau_{K}^{i}=-\frac{K_{t} F_{L}^{i} N^{i}\left(1-l^{i}\right)}{F_{K}^{i} K_{t}^{i}}, \quad \tau_{L}^{i}=-\frac{\eta\left(1-l^{i}\right)}{l^{i}-\eta\left(1-l^{i}\right)}=-\tau_{C}^{i}
$$

in all regions. This tax policy will maximize both growth and welfare.

\section{Regional Government Behavior}

After deriving the efficiency-supporting tax system let us now turn to the optimal tax policy from the regional government's point of view. We assume that a government in region $i$ maximizes the utility of a representative family residing in its region by setting $\tau_{K}^{i}$ and $\tau_{L}^{i}$ while $\tau_{C}^{i}$ automatically adjusts to satisfy the government's budget constraint (10e). While choosing its tax policy, the regional government acts under the Nash assumption that all other regions do not respond by changing their tax rates. Inserting (11) in (12) the regional government's problem becomes

$$
\begin{aligned}
\max \quad U_{t}^{i} & =\frac{1}{(1-\rho)} \ln \left[\frac{R}{N^{i}}\left(N^{i} K_{t}-K_{t}^{i}\right)+\frac{F^{i}\left(K_{t} L^{i}, K_{t}^{i}\right)}{N^{i}}-(1-\rho) K_{t}\right] \\
& +\frac{\rho}{(1-\rho)^{2}} \ln \rho R+\frac{\eta}{(1-\rho)} \ln l^{i} .
\end{aligned}
$$

After some algebraic steps making use of (10c) and (11) the first-order conditions for the optimal tax policy are

$$
\begin{aligned}
\frac{\partial U_{t}^{i}}{\partial \tau_{X}^{i}} & =\frac{1}{(1-\rho) N^{i} c_{t}^{i}}\left\{\left(N^{i} K_{t}-K_{t}^{i}\right) \frac{\partial R}{\partial \tau_{X}^{i}}+\tau_{K}^{i} F_{K}^{i} \frac{\partial K_{t}^{i}}{\partial \tau_{X}^{i}}\right. \\
& +\frac{\rho}{(1-\rho) R}\left[\tau_{K}^{i} F_{K}^{i} K_{t}^{i}+K_{t} F_{L}^{i} N^{i}\left(1-l^{i}\right)\right] \frac{\partial R}{\partial \tau_{X}^{i}}
\end{aligned}
$$




$$
\left.+\left(\frac{\tau_{C}^{i}+\tau_{L}^{i}}{1+\tau_{C}^{i}}\right) K_{t} F_{L}^{i} N^{i} \frac{\partial l^{i}}{\partial \tau_{X}^{i}}\right\}=0 \quad X=K, L .
$$

This expression can be simplified. Firstly, since we concentrate on identical regions, all governments choose the same tax rates and in equilibrium $N^{i} K_{t}=K_{t}^{i}$. Thus, we can ignore the terms-of-trade effect in the following. ${ }^{6}$ Secondly, as is shown in the appendix, the optimal tax policy implies

$$
\tau_{L}^{i}=-\tau_{C}^{i}
$$

indicating that the regional government has no incentive to distort the consumptionleisure choice of its residents. Now the above first--order conditions reduce to

$$
\begin{array}{r}
\frac{\partial U_{t}^{i}}{\partial \tau_{X}^{i}}=\frac{1}{(1-\rho) N^{i} c_{t}^{i}}\left\{\tau_{K}^{i} F_{K}^{i} \frac{\partial K_{t}^{i}}{\partial \tau_{X}^{i}}+\frac{\rho}{(1-\rho) R}\left[\tau_{K}^{i} F_{K}^{i} K_{t}^{i}+K_{t} F_{L}^{i} N^{i}\left(1-l^{i}\right)\right] \frac{\partial R}{\partial \tau_{X}^{i}}\right\}=0 \\
(21) \\
X=K, L .
\end{array}
$$

The first term in the curly brackets gives the effect of changing one of the tax rates on the consumption possibilities in period $t$. Any increase in the tax rates drives capital out of the region reducing both current production and consumption. The second term denotes the effect on future consumption possibilities. Any increase in one of the tax rates reduces the interest rate and, thus, the growth factor in the federation. This reduces the utility of a representative family even more.

In the case of identical regions we are able to determine the optimal tax rates. As is shown in the appendix, the first-order conditions of an optimal behavior of the government (21) can be used to solve explicitly for the optimal tax rate on capital income

$$
\tau_{K}^{i}=-\frac{K_{t} F_{L}^{i} N^{i}\left(1-l^{i}\right)}{F_{K}^{i} K_{t}^{i}[1-(1-\rho) \epsilon(I-1) / \rho]} \quad \text { where } \quad \epsilon \equiv \frac{d K_{t}^{i}}{d R} \frac{R}{K_{t}^{i}}<0 .
$$

Comparing (22) with the first-best solution (17b) we can derive some important results. First, as in the case of a central planner, a regional government will subsidize capital income in order to raise the private return towards the social return. But the

\footnotetext{
${ }^{6}$ The terms-of-trade effect can also be ignored in the case of many regions, $I \rightarrow \infty$, since from the viewpoint of a government in a (very) small open economy the tax policy has no effect on the interest rate within the federation.
} 
government will choose the first-best subsidy if (and only if) there is no other region, $I=1$, i.e. in the case of a closed economy as analyzed by Turnovsky (2000). In all other cases, $I>1$, the subsidy rate will be too low. If there is perfect competition among regions, $I \rightarrow \infty$, the case of a (very) small open economy, the government would abstain from subsidizing capital income at all, $\tau_{K}^{i}=0 .{ }^{7}$

Finally, inserting (20) and (22) into the regional government's budget constraint (10e) gives us the explicit optimal labor and consumption tax rate in the case of identical regions as

$$
\tau_{L}^{i}=-\frac{\eta\left(1-l^{i}\right) / l^{i}}{\left[1-\eta\left(1-l^{i}\right) / l^{i}\right][1-(1-\rho) \epsilon(I-1) / \rho]}=-\tau_{C}^{i}
$$

Since the capital subsidy is lower than in the first-best tax system, the subsidy rate on labor income and the tax rate on consumption are also smaller. In the case of a small open economy, $I \rightarrow \infty$, there is no need for tax revenue since the capital subsidy should be zero and, thus, $\tau_{L}^{i}=-\tau_{C}^{i}=0$. In summary we can state

Proposition 2: A regional government that maximizes the welfare of its immobile residents in the case of identical regions will subsidize mobile capital employed in the region. But it will choose an inefficiently low level of subsidization which depends on the total number of regions. Moreover, the regional government will offset any wage subsidy by an equivalent consumption tax so as not to distort the consumptionleisure choice of its residents, irrespective of the number of regions.

How can we explain the behavior of regional governments? While designing its optimal tax policy, the government compares the costs and benefits from its point of view. The benefit of a higher subsidy to capital and labor is that people will invest more in capital and expand their labor supply, increasing the growth factor and, thus, output and consumption in the future. But this policy has to be financed by a higher consumption tax, reducing today's consumption. In a closed economy this policy does not change the resource constraint of the region. But in the case of an

\footnotetext{
${ }^{7}$ This finding reflects the results derived by Wilson (1986) and Zodrow and Mieszkowski (1986) for interregional tax competition in a static world, and by Turnovsky (1999) with regard to the optimal fiscal policy in a small open economy.
} 
open economy, capital is mobile and the government has to take into account that its policy attracts capital from abroad, which increases its subsidy expenditures for given $\tau_{K}^{i}$ and $\tau_{L}^{i}$. Thus, there is a second cost component of subsidizing capital (and labor) from the regional government's point of view. As pointed out by Wildasin (1989), this second cost component represents a fiscal externality. When increasing its subsidy a single region does not take into account that all other regions will lose capital and thus their government expenditures will be reduced. As long as this fiscal externality is not internalized, a single region assesses the costs of subsidizing capital higher than would a federal government. ${ }^{8}$ At the same time the regional government has no incentive and no need to distort the consumption-leisure choice since it can achieve its objective entirely by choice of the capital income tax rate $\tau_{K}^{i} \cdot{ }^{9}$

\section{Concluding Discussion}

The above analysis extends the rather pessimistic view on the welfare impacts of interregional tax competition. We have not only to fear that governments will undersupply public goods and services if they must rely on taxes on mobile factors. It may be expected that tax competition is also harmful for growth. But there are several ways to improve the situation as we may learn by the existing literature. One possibility is a cooperation among the regions in their tax and expenditure policy. A second possible remedy is to establish a central government forcing all regions to choose the first-best tax system. Whereas this intervention may be seen as inappropriately strong, a central government could also ensure an efficient allocation by providing a system of matching grants in the line of Wildasin (1989).

\footnotetext{
${ }^{8}$ Note that the regional governments' conjecture that capital will be attracted by an increase of the subsidy rates actually proves to be wrong in the case of identical regions. Since all regions will choose the same tax rates in equilibrium, the interregional allocation of capital is independent from the level of the tax rates.

${ }^{9}$ Due to this finding we may assume that the same results with regard to the optimal capital tax rates will be obtained in the case of inelastically supplied labor. In this scenario, however, the tax on labor is equivalent to the consumption tax: Both work as a lump sum tax and should be positive.
} 
Beside these recommendations to improve the political arrangements there are also good arguments for being not too pessimistic from a theoretical point of view. As summarized in Wellisch (2000), interregional household mobility may work as an incentive mechanism for regional governments to choose a first-best policy. The intuition runs as follows: In designing their optimal policy, governments take into account migration responses of mobile households. Thus, they do not only pay attention to the effects on their own residents' utility but also on the welfare of non-residents. In the case of perfect household mobility, equalizing any differences in the utility between regions, each regional government would actually maximize the welfare of all families living in the federal state and would choose the first-best policy. A second caveat arises from reducing the time horizon of households. In the above analysis infinitely living households consume their entire labor income while investing only a part of their capital income. Therefore, a growth-enhancing policy needs to subsidize capital income. Now suppose the standard two-period lifetime overlapping generations model in the tradition of Diamond (1965) without any bequest motive. In this world households finance their entire capital investment out of their labor income in the first period of life. Thus, as pointed out by Uhlig and Yanagawa (1996), the growth-enhancing policy needs to shift resources from the old to the young generation. The analysis of the optimal tax policy design in the presence of tax competition depending on the time horizon of households is on the agenda for future research.

Finally, we conclude with an important caveat: While the simple Romer-model used in this paper has the advantage of providing a tractable framework for investigating the relationship of tax competition and growth and its policy implications, it also has the limitation that the economy is always on its balanced growth path. It therefore can not address issues pertaining to the dynamics of the economy. This opens a wide range for future work. 


\section{Appendix}

In this appendix we firstly derive the macroeconomic equilibrium showing that the federation with identical regions is always on a balanced growth path. Moreover, we examine the effects of changes in taxes and derive the optimal tax policy of regional governments.

\section{Derivation of the macroeconomic equilibrium}

Here we focus on the macroeconomic equilibrium with identical regions. With minor modifications the case of non-identical regions can be analyzed analogously.

In the case of identical regions, all governments will impose the same tax rates in equilibrium. Thus, all regions will employ the same amount of capital and labor in all periods:

$$
K_{t} N^{i}=K_{t}^{i} \quad \text { and } \quad l_{t}^{i}=l_{t}^{j}, \quad i, j=1, \ldots, I .
$$

Due to the linear homogeneity of the production function this also implies that, in equilibrium, the marginal products of capital and labor only depend on $l_{t}^{i}$. Furthermore, the growth factor of capital and wage rates have to be the same in all regions,

$$
\frac{K_{t+1}^{i}}{K_{t}^{i}}=\frac{K_{t+1}^{j}}{K_{t}^{j}}=\frac{K_{t+1}}{K_{t}} \quad \text { and } \quad \frac{w_{t+1}^{i}}{w_{t}^{i}}=\frac{w_{t+1}^{j}}{w_{t}^{j}} \quad i, j=1, \ldots I .
$$

Using this result in (6c) reveals that leisure also grows with the same factor in all regions:

(A.3) $\frac{l_{t+1}^{i}}{l_{t}^{i}}=\frac{l_{t+1}^{j}}{l_{t}^{j}} \quad$ where $\quad \frac{l_{t+1}^{i}}{l_{t}^{i}}=\rho\left(1-\tau_{K}^{i}\right) F_{K}^{i} \frac{K_{t} F_{L}^{i}}{K_{t+1} F_{L}^{i}}, \quad i, j=1, \ldots I$.

Since time endowment of households is bounded, in a steady-state equilibrium leisure has to reach a stationary level in all regions, $l^{i}=l^{j}$. Thus, in this steady-state equilibrium the growth factors of capital and wage rates are the same and equal to the overall growth factor

$$
\frac{K_{t+1}^{i}}{K_{t}^{i}}=\frac{K_{t+1}}{K_{t}}=\frac{w_{t+1}^{i}}{w_{t}^{i}}=\frac{c_{t+1}^{i}}{c_{t}^{i}}=\rho\left(1-\tau_{K}^{i}\right) F_{K}^{i}, \quad i=1, \ldots, I
$$


Finally, inserting (2) and (6a) in (4) gives us the growth factor of capital in the steady-state as

$$
\frac{K_{t+1}}{K_{t}}=\left(1-\tau_{K}^{i}\right) F_{K}^{i}+\left(1-\tau_{L}^{i}\right) F_{L}^{i}\left[1-l^{i}\left(\frac{1+\eta}{\eta}\right)\right] .
$$

Combining (A.4) with (4) reveals that each household uses her entire current labor income and a part of her capital income for private consumption in the steady-state:

$$
\left(1+\tau_{C}^{i}\right) c_{t}^{i}=(1-\rho) K_{t}+\left(1-\tau_{L}^{i}\right) w_{t}^{i}\left(1-l^{i}\right)
$$

Moreover, combining (A.4) with (A.5) yields

$$
(\rho-1)\left(1-\tau_{K}^{i}\right) F_{K}^{i}=\left(1-\tau_{L}^{i}\right) F_{L}^{i}\left[1-l^{i}\left(\frac{1+\eta}{\eta}\right)\right] \Rightarrow l^{i}>\frac{\eta}{1+\eta}
$$

showing that there is a lower bound for $l^{i}$ to ensure that at least some of the capital income will be consumed, too.

Now we will show that $l_{t}^{i}$ is actually constant over time in equilibrium so that the federation is in fact always on its balanced growth path characterized by the above equations. Inserting (A.5) into (6c) and linearizing around the steady-value $l^{i}$ gives us the difference equation

$$
\text { (A.7) } \begin{aligned}
\frac{d l_{t+1}^{i}}{d l_{t}^{i}} & =\frac{G\left(l^{i}\right)}{Q\left(l^{i}\right)}, \text { where } \\
G\left(l^{i}\right) & =\rho R\left(F_{L}^{i}-F_{L L}^{i} l^{i}\right)+\left(1-\tau_{K}^{i}\right) F_{K L}^{i} F_{L}^{i} l^{i} \\
& +\left(1-\tau_{L}^{i}\right) F_{L}^{i} l^{i}\left\{F_{L L}^{i}\left[1-l^{i}\left(\frac{1+\eta}{\eta}\right)\right]+F_{L}^{i}\left(\frac{1+\eta}{\eta}\right)\right\}>0 \\
Q\left(l^{i}\right) & =\rho R\left(F_{L}^{i}-F_{L L}^{i} l^{i}\right)+\rho\left(1-\tau_{K}^{i}\right) F_{K L}^{i} F_{L}^{i} l^{i}>0 .
\end{aligned}
$$

Since $l^{i}>\eta /(1+\eta)$ and $\rho<1, G\left(l^{i}\right)>Q\left(l^{i}\right)$ and

$$
\frac{d l_{t+1}^{i}}{d l_{t}^{i}}>1
$$

indicating that (A.7) is an unstable difference equation. The only solution consistent with an equilibrium is that leisure has to be constant in all periods and equal to its steady-state value, $l_{t}^{i}=l_{t+1}^{i}=l^{i}$. 


\section{Comparative static analysis}

To derive the effects of changes in taxes we use (2), (3), (8), and (11) to get the system

(A.8) $\rho R=\frac{R}{K_{t} N^{i}}\left(N^{i} K_{t}-K_{t}^{i}\right)+F_{K}^{i} \frac{K_{t}^{i}}{K_{t} N^{i}}+F_{L}^{i}\left[1-l^{i}-\left(\frac{1-\tau_{L}^{i}}{1+\tau_{C}^{i}}\right) \frac{l^{i}}{\eta}\right]$,

(A.9) $\quad R=\left(1-\tau_{K}^{i}\right) F_{K}^{i}$

which can be written (valued in equilibrium) as

$$
\left[\begin{array}{ll}
a_{11} & a_{12} \\
a_{21} & a_{22}
\end{array}\right]\left[\begin{array}{c}
d K_{t}^{i} \\
d l^{i}
\end{array}\right]=\left[\begin{array}{cccc}
\rho d R & 0 & -\frac{F_{L}^{i} l^{i}}{\left(1+\tau_{C}^{i}\right) \eta} d \tau_{L}^{i} & -\left(\frac{1-\tau_{L}^{i}}{1+\tau_{C}^{i}}\right) \frac{F_{L}^{i} l^{i}}{\left(1+\tau_{C}^{i}\right) \eta} d \tau_{C}^{i} \\
d R & F_{K}^{i} d \tau_{K}^{i} & 0 & 0
\end{array}\right]
$$

where

$$
\begin{aligned}
& a_{11}=\tau_{K}^{i} \frac{F_{K}^{i}}{K_{t} N^{i}}+F_{K K}^{i}+F_{L K}^{i}\left[1-l^{i}-\left(\frac{1-\tau_{L}^{i}}{1+\tau_{C}^{i}}\right) \frac{l^{i}}{\eta}\right] \\
& a_{12}=-\left\{F_{K L}^{i} K_{t} N^{i}+F_{L L}^{i}\left[1-l^{i}-\left(\frac{1-\tau_{L}^{i}}{1+\tau_{C}^{i}}\right) \frac{l^{i}}{\eta}\right]+F_{L}^{i}\left[1+\left(\frac{1-\tau_{L}^{i}}{1+\tau_{C}^{i}}\right)\right]\right\}<0 \\
& a_{21}=\left(1-\tau_{K}^{i}\right) F_{K K}^{i}<0 \\
& a_{22}=-\left(1-\tau_{K}^{i}\right) F_{K L}^{i} K_{t} N^{i}<0 .
\end{aligned}
$$

In the following we assume that $a_{11}$ is negative, which is certainly the case when there is no taxation or in the optimum. The determinant of the coefficient matrix is

$$
\begin{aligned}
\Delta & =\left(1-\tau_{K}^{i}\right) K_{t} N^{i}\left[1-l^{i}-\left(\frac{1-\tau_{L}^{i}}{1+\tau_{C}^{i}}\right) \frac{l^{i}}{\eta}\right]\left[F_{K K}^{i} F_{L L}^{i}-\left(F_{K L}^{i}\right)^{2}\right] \\
& +\left(1-\tau_{K}^{i}\right) F_{K K}^{i} F_{L}^{i}\left[1+\left(\frac{1-\tau_{L}^{i}}{1+\tau_{C}^{i}}\right) \frac{1}{\eta}\right]-\tau_{K}^{i}\left(1-\tau_{K}^{i}\right) F_{K L}^{i} F_{K}^{i}
\end{aligned}
$$

We assume that $\Delta$ is negative, which is definitely the case when starting from a situation without taxation, $\tau_{X}^{i}=0$ and $X=K, L, C$. Using Cramer's rule we get

$$
\begin{aligned}
\frac{d K_{t}^{i}}{d R} & =-\frac{a_{12}-\rho a_{22}}{\Delta}<0, \quad \frac{d l^{i}}{d R}=\frac{a_{11}-\rho a_{21}}{\Delta}>0 \\
\frac{d K_{t}^{i}}{d \tau_{K}^{i}} & =-F_{K}^{i} \frac{a_{12}}{\Delta}<0, \quad \frac{d s l^{i}}{d \tau_{K}^{i}}=F_{K}^{i} \frac{a_{11}}{\Delta}>0 \\
\frac{d K_{t}^{i}}{d \tau_{L}^{i}} & =-\frac{F_{L}^{i} l^{i}}{\left(1+\tau_{C}^{i}\right) \eta} \frac{a_{22}}{\Delta}<0, \quad \frac{d l^{i}}{d \tau_{L}^{i}}=\frac{F_{L}^{i} l^{i}}{\left(1+\tau_{C}^{i}\right) \eta} \frac{a_{21}}{\Delta}>0 \\
\frac{d K_{t}^{i}}{d \tau_{C}^{i}} & =\left(\frac{1-\tau_{L}^{i}}{1+\tau_{C}^{i}}\right) \frac{d K_{t}^{i}}{d \tau_{L}^{i}}<0, \quad \frac{d l^{i}}{d \tau_{C}^{i}}=\left(\frac{1-\tau_{L}^{i}}{1+\tau_{C}^{i}}\right) \frac{d l^{i}}{d \tau_{L}^{i}}>0 .
\end{aligned}
$$


Equipped with these equations we are able to determine the responses of $R, K_{t}^{i}, K_{t}^{j}$, $l^{j}$, and $l^{i}$ on tax changes. Here we derive the reaction on a change in the labor income $\operatorname{tax} \tau_{L}^{i}$. The remaining can be obtained analogously. First, we derive the response on the interest rate. For this we start with the federal capital constraint (10g) to get

$$
\frac{d R}{d \tau_{L}^{i}}+\sum_{i=1}^{I} \frac{d K_{t}^{i}}{d R} \frac{\partial R}{\partial \tau_{L}^{i}}=0
$$

Inserting the corresponding expressions from (A.11) yields for the case of identical regions

$$
\frac{\partial R}{\partial \tau_{L}^{i}}=-\frac{F_{L}^{i} l^{i}}{\left(1+\tau_{C}^{i}\right) \eta} \frac{a_{12}}{I\left(a_{12}-\rho a_{22}\right)}<0 .
$$

Using this key response we may easily derive the behavior of the capital employed in region $i$ and $j$ as

$$
\begin{aligned}
\frac{\partial K_{t}^{i}}{\partial \tau_{L}^{i}} & =\frac{d K_{t}^{i}}{d \tau_{L}^{i}}+\frac{d K_{t}^{i}}{d R} \frac{d R}{d \tau_{L}^{i}}=-\frac{F_{L}^{i} l^{i}}{\left(1+\tau_{C}^{i}\right) \eta} \frac{a_{22}}{I \Delta}(I-1)<0 \\
\frac{\partial K_{t}^{j}}{\partial \tau_{L}^{i}} & =\frac{d K_{t}^{j}}{d R} \frac{d R}{d \tau_{L}^{i}}=\frac{F_{L}^{i} l^{i}}{\left(1+\tau_{C}^{i}\right) \eta} \frac{a_{22}}{I \Delta}>0, \quad j \neq i .
\end{aligned}
$$

Correspondingly, we can obtain the reaction of leisure in the regions as

$$
\begin{aligned}
\frac{\partial l^{i}}{\partial \tau_{L}^{i}} & =\frac{F_{L}^{i} l^{i}}{\left(1+\tau_{C}^{i}\right) \eta} \frac{1}{\left(\rho a_{22}-a_{12}\right)}>0 \\
\frac{\partial l^{j}}{\partial \tau_{L}^{i}} & =-\frac{F_{L}^{i} l^{i}}{\left(1+\tau_{C}^{i}\right) \eta} \frac{a_{22}\left(\rho a_{21}-a_{11}\right)}{I \Delta\left(\rho a_{22}-a_{12}\right)}<0, \quad j \neq i .
\end{aligned}
$$

Analogously, we get the corresponding effects due to a change in the capital tax rate as

$$
\begin{aligned}
\frac{\partial R}{\partial \tau_{K}^{i}} & =\frac{F_{K}^{i}}{I} \frac{a_{12}}{\left(\rho a_{22}-a_{12}\right)}<0 \\
\frac{\partial K_{t}^{i}}{\partial \tau_{K}^{i}} & =-\frac{F_{K}^{i}}{\Delta} \frac{a_{12}}{I}(I-1)=-\frac{\partial K_{t}^{j}}{\partial \tau_{K}^{i}}(I-1)<0, \quad j \neq i \\
\frac{\partial l^{i}}{\partial \tau_{K}^{i}} & =\frac{F_{K}^{i}}{\Delta I\left(\rho a_{22}-a_{12}\right)}\left[I a_{11}\left(\rho a_{22}-a_{12}\right)+a_{12}\left(a_{11}-\rho a_{12}\right)\right]>0 \\
\frac{\partial l^{j}}{\partial \tau_{L}^{i}} & =-\frac{F_{K}^{i}}{\Delta I} \frac{a_{12}\left(a_{11}-\rho a_{21}\right)}{\left(\rho a_{22}-a_{12}\right)}<0, \quad j \neq i .
\end{aligned}
$$




\section{Optimal regional government policy}

To derive the optimal regional policy in the case of identical regions we rewrite (19) using $K_{t} N^{i}=K_{t}^{i}$ :

$$
\begin{aligned}
\frac{\partial U_{t}^{i}}{\partial \tau_{X}^{i}} & =\frac{1}{(1-\rho) N^{i} c_{t}^{i}}\left\{\tau_{K}^{i} F_{K}^{i} \frac{\partial K_{t}^{i}}{\partial \tau_{X}^{i}}+\frac{\rho}{(1-\rho) R}\left[\tau_{K}^{i} F_{K}^{i} K_{t}^{i}+K_{t} F_{L}^{i} N^{i}\left(1-l^{i}\right)\right] \frac{\partial R}{\partial \tau_{X}^{i}}\right. \\
(\mathrm{A} .18) & \left.+\left(\frac{\tau_{C}^{i}+\tau_{L}^{i}}{1+\tau_{C}^{i}}\right) K_{t} F_{L}^{i} N^{i} \frac{\partial l^{i}}{\partial \tau_{X}^{i}}\right\}=0 \quad X=K, L .
\end{aligned}
$$

Dividing by $\partial R / \partial \tau_{X}^{i}, X=K, L$, and using the results of (A.12)-(A.17) we can state that

$$
\frac{\partial U_{t}^{i}}{\partial \tau_{K}^{i}}=\frac{\partial U_{t}^{i}}{\partial \tau_{L}^{i}}=0 \quad \text { if and only if } \quad\left(\frac{\tau_{C}^{i}+\tau_{L}^{i}}{1+\tau_{C}^{i}}\right) \frac{\partial l^{i}}{\partial \tau_{K}^{i}} \frac{\partial \tau_{K}^{i}}{\partial R}=\left(\frac{\tau_{C}^{i}+\tau_{L}^{i}}{1+\tau_{C}^{i}}\right) \frac{\partial l^{i}}{\partial \tau_{L}^{i}} \frac{\partial \tau_{L}^{i}}{\partial R}
$$

Since

$$
\frac{\partial l^{i}}{\partial \tau_{K}^{i}} \frac{\partial \tau_{K}^{i}}{\partial R} \neq \frac{\partial l^{i}}{\partial \tau_{L}^{i}} \frac{\partial \tau_{L}^{i}}{\partial R} \neq 0,
$$

the first-order conditions for the optimal tax policy of the regional government can only be met, if

$$
\tau_{L}^{i}=-\tau_{C}^{i},
$$

restating equation (20) in the main text. 


\section{References}

Brueckner, J. K., 1999, Fiscal Federalism and Capital Accumulation, Journal of Public Economic Theory, 1, pp. 205-224.

Brueckner, J. K., 2005, Fiscal Federalism and Economic Growth, CESifo Working Paper No. 1601.

Diamond, P., 1965, National Debt in a Neoclassical Growth Model, American Economic Review, 55, pp. 1126-1150.

Frankel, M., 1962, The Production Function in Allocation and Growth: A Synthesis, American Economic Review, 55, pp. 296-319.

Fuest, C. and B. Huber, 2001, Labor and Capital Income Taxation, Fiscal Competition, and the Distribution of Wealth, Journal of Public Economics, 89, pp. $71-91$.

García-Peñalosa, C. and S. J. Turnovsky (2006), Growth, Income Inequality and Fiscal Policy: What are the relevant Tradeoffs?, Journal of Money, Credit, and Banking, 39, pp. 369-394.

Koskela, E. and R. Schöb, 2002, Optimal Factor Income Taxation in the Presence of Unemployment, Journal of Public Economic Theory, 4, pp. 387-404.

Lejour, A. M. and H. A. A. Verbon, 1997, Tax Competition and Redistribution in a Two-Country Endogenous-Growth Model, International Tax and Public Finance, 4, pp. 485-497.

Rauscher, M., 2005, Economic Growth and Tax-Competing Leviathans, International Tax and Public Finance, 12, pp. 457-474.

Romer, P.M., 1986, Increasing Returns and Long-run Growth, Journal of Political Economy, 94, pp. 1002-137.

Tiebout, C. M., 1956, A Pure Theory of Local Expenditures, Journal of Political Economy, 64, pp. 416-424. 
Turnovsky, S. J., 1999, Fiscal Policy and Growth in a Small Open Economy with Elastic Labor Supply, Canadian Journal of Economics, 32, pp. 1191-1213.

Turnovsky, S. J., 2000, Fiscal Policy, Elastic Labor Supply, and Endogenous Growth, Journal of Monetary Economics, 45, pp. 185-210.

Uhlig, H. and N. Yanagawa, 1996, Increasing the Capital Income Tax may lead to faster Growth, European Economic Review, 40, pp. 1521-1540.

Wellisch, D., 2000, Theory of Public Finance in a Federal State, Cambridge: Cambridge University Press.

Wildasin, D., 1989, Interjurisdictional Capital Mobility: Fiscal Externality and a Corrective Subsidy, Journal of Urban Economics, 25, pp. 193-212.

Wilson, J. D., 1986, A Theory of Interregional Tax Competition, Journal of Urban Economics, 19, pp. 296-315.

Wilson, J. D., 1999, Theories of Tax Competition, National Tax Journal, 52, pp. 269-304.

Zodrow, G. R. and P. Mieszkowski, 1986, Pigou, Tiebout, Property Taxation, and the Underprovision of Local Public Goods, Journal of Urban Economics, 19, pp. 356-370. 


\section{CESifo Working Paper Series}

for full list see www.cesifo-group.org/wp

(address: Poschingerstr. 5, 81679 Munich, Germany, office@cesifo.de)

2277 Bas Jacobs, Is Prescott Right? Welfare State Policies and the Incentives to Work, Learn and Retire, April 2008

2278 Burkhard Heer and Alfred Maußner, Value Function Iteration as a Solution Method for the Ramsey Model, April 2008

2279 Jarko Fidrmuc and Christa Hainz, Integrating with their Feet: Cross-Border Lending at the German-Austrian Border, April 2008

2280 Kristof Dascher and Alexander Haupt, The Political Economy of Regional Integration Projects at Borders where Rich and Poor Meet: The Role of Cross-Border Shopping and Community Sorting, April 2008

2281 Katrin Assenmacher-Wesche and M. Hashem Pesaran, A VECX* Model of the Swiss Economy, April 2008

2282 Christophe Rault, Robert Sova and Ana Maria Sova, Modeling International Trade Flows between CEEC and OECD Countries, April 2008

2283 Timo Boppart, Josef Falkinger, Volker Grossmann, Ulrich Woitek and Gabriela Wüthrich, Qualifying Religion: The Role of Plural Identities for Educational Production, April 2008

2284 Armin Falk, David Huffman and W. Bentley MacLeod, Institutions and Contract Enforcement, April 2008

2285 Axel Dreher and Stefan Voigt, Does Membership in International Organizations Increase Governments' Credibility? Testing the Effects of Delegating Powers, April 2008

2286 Xavier Freixas and Bruno M. Parigi, Lender of Last Resort and Bank Closure Policy, April 2008

2287 Regina Dionisius, Samuel Muehlemann, Harald Pfeifer, Günter Walden, Felix Wenzelmann and Stefan C. Wolter, Cost and Benefit of Apprenticeship Training - A Comparison of Germany and Switzerland, April 2008

2288 Francesco Daveri and Cecilia Jona-Lasinio, Off-Shoring and Productivity Growth in the Italian Manufacturing Industries, April 2008

2289 Mikael Priks, Do Surveillance Cameras Affect Unruly Behavior? A Close Look at Grandstands, April 2008

2290 Marianna Belloc and Daniela Federici, A Two-Country NATREX Model for the Euro/Dollar, April 2008 
2291 Nicolas Treich, The Value of a Statistical Life under Ambiguity Aversion, April 2008

2292 J. Atsu Amegashie, Socially-Tolerable Discrimination, April 2008

2293 M. Hashem Pesaran and Andreas Pick, Forecasting Random Walks Under Drift Instability, April 2008

2294 Steven Brakman, Gus Garita, Harry Garretsen and Charles van Marrewijk, Unlocking the Value of Cross-Border Mergers and Acquisitions, May 2008

2295 Eric O’N. Fisher and Kathryn G. Marshall, The Structure of the American Economy, May 2008

2296 Claudia M. Buch and Martin Schlotter, Regional Origins of Employment Volatility: Evidence from German States, May 2008

2297 Helmuth Cremer, Philippe De Donder, Dario Maldonado and Pierre Pestieau, Taxing Sin Goods and Subsidizing Health Care, May 2008

2298 Reinhilde Veugelers and Frederick van der Ploeg, Reforming European Universities: Scope for an Evidence-Based Process, May 2008

2299 Jon H. Fiva and Lars J. Kirkebøen, Does the Housing Market React to New Information on School Quality?, May 2008

2300 Tina Klautke and Alfons J. Weichenrieder, Interest Income Tax Evasion, the EU Savings Directive, and Capital Market Effects, May 2008

2301 Harald Badinger and Peter Egger, GM Estimation of Higher Order Spatial Autoregressive Processes in Panel Data Error Component Models, May 2008

2302 Jan K. Brueckner, Slot-Based Approaches to Airport Congestion Management, May 2008

2303 Sören Blomquist, Vidar Christiansen and Luca Micheletto, Public Provision of Private Goods and Nondistortionary Marginal Tax Rates, May 2008

2304 Dan Anderberg and Alessandro Balestrino, The Political Economy of Post-Compulsory Education Policy with Endogenous Credit Constraints, May 2008

2305 Tomer Blumkin, Yoram Margalioth and Efraim Sadka, The Role of Stigma in the Design of Welfare Programs, May 2008

2306 Vesa Kanniainen and Paolo M. Panteghini, Tax Neutrality: Illusion or Reality? The Case of Entrepreneurship, May 2008

2307 Thomas Dohmen, Armin Falk, David Huffman and Uwe Sunde, The Intergenerational Transmission of Risk and Trust Attitudes, May 2008 
2308 Guglielmo Maria Caporale and Mario Cerrato, Using Chebyshev Polynomials to Approximate Partial Differential Equations, May 2008

2309 Peter Egger and Doina Maria Radulescu, Labour Taxation and Foreign Direct Investment, May 2008

2310 Laurent Linnemer, Dissipative Advertising Signals Quality even without Repeat Purchases, May 2008

2311 Jordi Jofre-Monseny and Albert Solé-Ollé, Which Communities should be afraid of Mobility? The Effects of Agglomeration Economies on the Sensitivity of Firm Location to Local Taxes, May 2008

2312 Andreas Haufler and Ferdinand Mittermaier, Unionisation Triggers Tax Incentives to Attract Foreign Direct Investment, May 2008

2313 Ronel Elul and Piero Gottardi, Bankruptcy: Is it enough to Forgive or must we also Forget?, May 2008

2314 Andreas Irmen and Johanna Kuehnel, Productive Government Expenditure and Economic Growth, May 2008

2315 Beate Henschel, Carsten Pohl and Marcel Thum, Demographic Change and Regional Labour Markets: The Case of Eastern Germany, May 2008

2316 Gabriel Felbermayr, Wido Geis and Wilhelm Kohler, Restrictive Immigration Policy in Germany: Pains and Gains Foregone?, May 2008

2317 Michael Hofmann, Gerhard Kempkes and Helmut Seitz, Demographic Change and Public Sector Budgets in a Federal System, May 2008

2318 Paul De Grauwe, Macroeconomic Modeling when Agents are Imperfectly Informed, June 2008

2319 Johann K. Brunner and Susanne Pech, Optimum Taxation of Inheritances, June 2008

2320 Thomas Eichner and Marco Runkel, Corporate Income Taxation of Multinationals in a General Equilibrium Model, June 2008

2321 Rainald Borck and Matthias Wrede, Subsidies for Intracity and Intercity Commuting, June 2008

2322 Patricia Apps and Ray Rees, Testing the Pareto Efficiency of Household Resource Allocations, June 2008

2323 Amihai Glazer, Vesa Kanniainen and Panu Poutvaara, Firms' Ethics, Consumer Boycotts, and Signalling, June 2008

2324 Claudia M. Buch, Jörg Döpke and Kerstin Stahn, Great Moderation at the Firm Level? Unconditional vs. Conditional Output Volatility, June 2008 
2325 Helmuth Cremer, Philippe De Donder, Dario Maldonado and Pierre Pestieau, Forced Saving, Redistribution and Nonlinear Social Security Schemes, June 2008

2326 M. Hashem Pesaran and Paolo Zaffaroni, Optimal Asset Allocation with Factor Models for Large Portfolios, June 2008

2327 Harald Badinger and Peter Egger, Horizontal versus Vertical Interdependence in Multinational Activity, June 2008

2328 Jan K. Brueckner and Harris Selod, A Theory of Urban Squatting and Land-Tenure Formalization in Developing Countries, June 2008

2329 Paolo M. Panteghini, Corporate Debt, Hybrid Securities and the Effective Tax Rate, June 2008

2330 Guglielmo Maria Caporale, Juncal Cuñado and Luis A. Gil-Alana, Modelling Long-Run Trends and Cycles in Financial Time Series Data, June 2008

2331 Avi Ben-Bassat and Momi Dahan, Social Identity and Voter Turnout, June 2008

2332 Martin R. West and Ludger Wößmann, "Every Catholic Child in a Catholic School”: Historical Resistance to State Schooling, Contemporary Private Competition, and Student Achievement across Countries, June 2008

2333 Erkki Koskela and Panu Poutvaara, Outsourcing and Labor Taxation in Dual Labor Markets, June 2008

2334 Philippe Choné and Laurent Linnemer, Optimal Litigation Strategies with Signaling and Screening, June 2008

2335 Albert Solé-Ollé and Pilar Sorribas-Navarro, Does Partisan Alignment Affect the Electoral Reward of Intergovernmental Transfers?, June 2008

2336 Antonio Cabrales and Piero Gottardi, Markets for Information: Of Inefficient Firewalls and Efficient Monopolies, June 2008

2337 Sumon Majumdar and Sharun W. Mukand, The Leader as Catalyst - on Leadership and the Mechanics of Institutional Change, June 2008

2338 Ulrich Hange, Tax Competition, Elastic Labor Supply, and Growth, June 2008 